\title{
Agricultural Use of Copper and Its Link to Alzheimer's Disease
}

Fábio C. Coelho ${ }^{1, * \mathbb{D}}$, Rosanna Squitti ${ }^{2, *}$, Mariacarla Ventriglia ${ }^{3}$, Giselle Cerchiaro ${ }^{4}$ (D) João P. Daher ${ }^{5}$, Jaídson G. Rocha ${ }^{1}{ }^{(D}$, Mauro C. A. Rongioletti ${ }^{6}$ and Anna-Camilla Moonen ${ }^{7}$ (D)

1 Phytotechnics Laboratory, Universidade Estadual do Norte Fluminense Darcy Ribeiro-UENF; Campos dos Goytacazes, RJ 28013-602, Brazil; jaidsongr@yahoo.com.br

2 Molecular Markers Laboratory, IRCCS Instituto Centro San Giovanni di Dio Fatebenefrate lli, 25125 Brescia, Italy

3 Fatebenefratelli Foundation for Health Research and Education, AFaR Division, 00186 Rome, Italy; mariacarla.ventriglia@afar.it

4 Center for Natural Science and Humanities, Federal University of ABC-UFABC, Santo André, SP 09210-580, Brazil; gicerchiaro@gmail.com

5 Hospital Universitário Antônio Pedro, Universidade Federal Fluminense, Niterói, RJ 24210-350, Brazil; jpldaher@gmail.com

6 Department of Laboratory Medicine, Research and Development Division, San Giovanni Calibita Fatebenefratelli Hospital, Isola Tiberina, 00186 Rome, Italy; biomolfbf@gmail.com

7 Land Lab, Institute of Life Sciences, Scuola Superiore Sant'Anna, 56127 Pisa, Italy; c.moonen@santannapisa.it

* Correspondence: fcoelho@uenf.br (F.C.C.); rosanna.squitti@afar.it (R.S.); Tel.: +55-22-998509469 (F.C.C.); $+39-066837546$ (R.S.)

Received: 18 May 2020; Accepted: 9 June 2020; Published: 12 June 2020

\begin{abstract}
Copper is an essential nutrient for plants, animals, and humans because it is an indispensable component of several essential proteins and either lack or excess are harmful to human health. Recent studies revealed that the breakdown of the regulation of copper homeostasis could be associated with Alzheimer's disease (AD), the most common form of dementia. Copper accumulation occurs in human aging and is thought to increase the risk of $\mathrm{AD}$ for individuals with a susceptibility to copper exposure. This review reports that one of the leading causes of copper accumulation in the environment and the human food chain is its use in agriculture as a plant protection product against numerous diseases, especially in organic production. In the past two decades, some countries and the EU have invested in research to reduce the reliance on copper. However, no single alternative able to replace copper has been identified. We suggest that agroecological approaches are urgently needed to design crop protection strategies based on the complementary actions of the wide variety of crop protection tools for disease control.
\end{abstract}

Keywords: heavy metal; dementia; organic agriculture; agroecology

\section{Alzheimer's Disease}

Alzheimer's disease (AD) is the most common cause of dementia in the elderly. The World Health Organization (WHO) [1] estimated the ranking of the top seven countries in the number of deaths caused by AD. In absolute numbers, the ranking was the China, USA; India, United Kingdom, Indonesia, France and Germany with 563.5; 259.5; 140.9; 82.5; 54.7, 49.6 and 48.8 thousand deaths in 2016, respectively.

The late-onset sporadic form of the disease appears after age 65, accounts for 90-95\% of AD cases and derives from a complex interaction of genetic and non-genetic factors. The early-onset familial $\mathrm{AD}$ represents a small portion of all $\mathrm{AD}$ cases and is due to mutations in APP, PSEN1 and PSEN2 
genes. The disease is caused by misfolding of specific proteins that are associated with extracellular deposits of the beta-amyloid $(\mathrm{A} \beta)$ protein $[2,3]$ and aberrant aggregation of pathological forms of the intraneuronal protein Tau [4].

Alzheimer's disease accounts for $60-80 \%$ of cases of dementia and autopsy studies indicate that $50 \%$ involve solely $\mathrm{AD}$ pathology [5]. A $\beta$ plaques may contribute to neurodegeneration, but the etiology of the disease is still unclear and several hypotheses have been posited. In the 1990s, the 'amyloid cascade' hypothesis became the dominant hypothesis. A consistent number of clinical trials focusing on $A \beta$ cleaving enzymes, antibodies or anti-A $\beta$ compounds so far, have provided negative results [6]. However, a recent re-evaluation (in December 2019) of results from a phase III clinical trial with aducanumab (EMERGE study), appears encouraging, suggesting that aducanumab can both remove $\mathrm{A} \beta$ plaques and slow cognitive decline in people with early AD. Surprisingly in the same month, China approved for AD treatment Oligomannate, and a phase III study was planned for starting in 2020 in China, the United States and Europe to authorize the marketing of the drug [7].

Besides these encouraging results that have still to be fully assessed, recent studies, pointing to prevention strategies, showed the predictive accuracy of the 'LIfestyle for BRAin Health' (LIBRA) score for dementia and mild cognitive impairment (MCI), a prodromal stage of the disease [8-11]. In this line, lifestyle intervention [12] has been shown to benefit cognition, as demonstrated by results from the FINGER [13], and the Rotterdam studies [14]. As a whole, the latest evidence points out to the multifactorial etiology of AD and the potential of preventive strategies to reduce the prevalence of the disease.

\section{Alzheimer's Disease and Copper}

Copper is an essential trace metal controlling human physiology. Brain cells use copper during development, and it is indispensable in vital processes such as respiration, energy production, formation of myelin sheath around neurons, synthesis of neurotransmitters, immune system responses, collagen and pigment synthesis and wound healings. We surveyed the number of papers in the medicine database on the biological connection between AD and copper. The search on 'Scopus' with the terms "Alzheimer's disease and copper" provided 3009 document results (Figure 1).

The stratification by 'subject area' of the Scientific Journals of publication can help depict the large areas of scientific articles published on this topic that enclose.

\subsection{Copper Connection with Alzheimer's Disease: Biochemistry Literature}

This literature includes Inorganic and Coordination Chemistry and is mostly focused on the interaction of $A \beta$ and the $A \beta$ precursor protein (APP, encoded by the APP gene) with copper. APP is a copper protein [15]. Consolidate knowledge indicates that the APP/A $\beta$ system is central for $\mathrm{AD}$ pathogenesis, and a recent view proposes that the $\mathrm{APP} / \mathrm{A} \beta$ system is centrally involved in neuronal copper transport at the synapses and in processes of learning and memory [16-18]. Loosely bound copper, as a transition metal, actively facilitates oxidative stress via Fenton like and Haber Weiss reactions. These reactions have been demonstrated to result in $\mathrm{A} \beta$ oligomer formation and their precipitation within plaques along with lipid peroxidation [19-22]. Established evidence demonstrated that: APP is a copper protein that binds and reduces copper from $\mathrm{Cu}$ (II) to $\mathrm{Cu}$ (I) [15], facilitating copper-induced toxicity in cell cultures and oxidative stress through the production of $\mathrm{H}_{2} \mathrm{O}_{2}$ [23]; that $\mathrm{A} \beta$ and metals are packed together in the brain $A \beta$ plaques $[15,24,25]$; that $A \beta$ plaques can be dissolved by chelating agents, which sequester the copper [24]. Overload of $\mathrm{Cu}(\mathrm{II})-\mathrm{A} \beta$ molecules are also probable, particularly at the synapses where both are released [16]: copper ions are released from synaptic vesicles reaching concentrations as high as $15 \mu \mathrm{mol} / \mathrm{L}$ in a form of labile copper, not bound to proteins [26]. These conditions facilitate $\mathrm{Cu}-\mathrm{A} \beta$ formation. At the same time, cell-associated copper into neurons could be decreased [27]. 


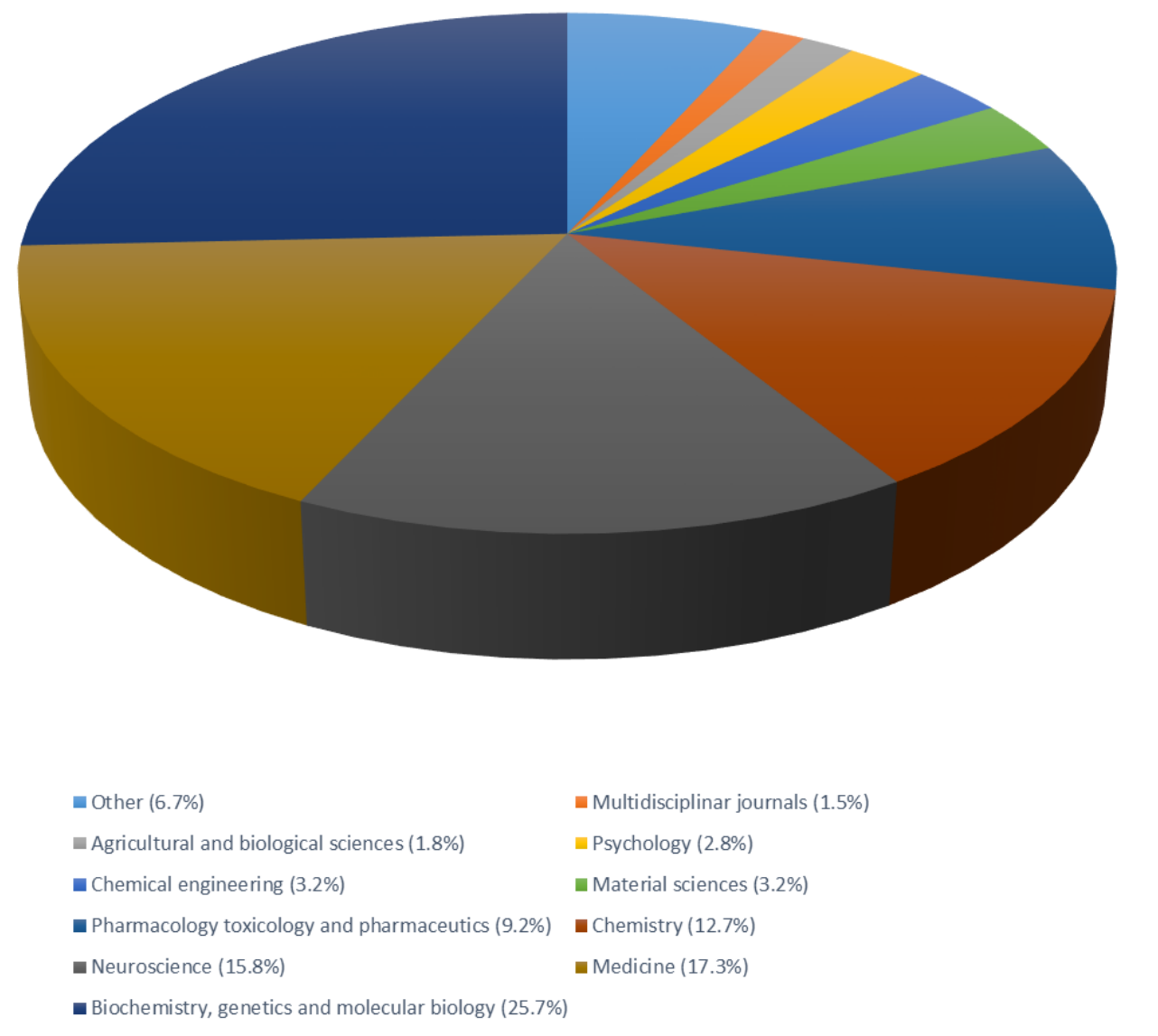

Figure 1. Pie chart illustrating the literature published on the topic 'Copper' and "Alzheimer's disease". Search on the Scopus research engine retrieved 3009 scientific articles; the stratification by 'subject area' reveals that $25.7 \%$ of the papers published come from the Biochemistry area, $17.3 \%$ from Medicine, $15.8 \%$ from Neuroscience, $12.7 \%$ from Chemistry and 9.2\% from Pharmacology.

\subsection{Copper Connection with Alzheimer's Disease: Medicine Literature}

Most of these studies focused on the comparison of copper levels in diverse organ tissues or biological matrices (e.g., serum, plasma, cerebrospinal fluid, brain, hair, nails). Most of these findings have been evaluated through meta-analyses that reported excess copper in general circulation [28-30] and copper deficiency in the brain [31]. The picture provided supports the evidence that patients with $\mathrm{AD}$ fail to maintain a correct metabolic balance and distribution of copper in the body [18]. In line with these findings, a recent meta-analysis has attributed the copper excess found in AD serum to the expansion of the fraction of exchangeable $\mathrm{Cu}^{2+}$ defined as copper not bound to ceruloplasmin (non-ceruloplasmin copper, also referred to as 'free' copper) [29]. This serum fraction is composed of copper loosely bound to albumin, $\alpha 2$ macroglobulin, peptides and amino acids and exchanged among them [29]. Non-ceruloplasmin copper has been already identified as a marker of Wilson disease, a rare inborn error of copper metabolism and a paradigm of non-ceruloplasmin copper toxicosis and accumulation [18]. Overall, existing meta-analyses in AD provided results of decreased levels of copper in the brain [31], along with a non-ceruloplasmin copper increase in serum/plasma [28-30,32,33], that accounts for copper excess in the bloodstream [34], in line with a number of clinical studies (Table 1). 
Table 1. Clinical studies analyzing the copper and $А T P 7 B$ link to Alzheimer's disease risk and the association with the subjects' clinical status.

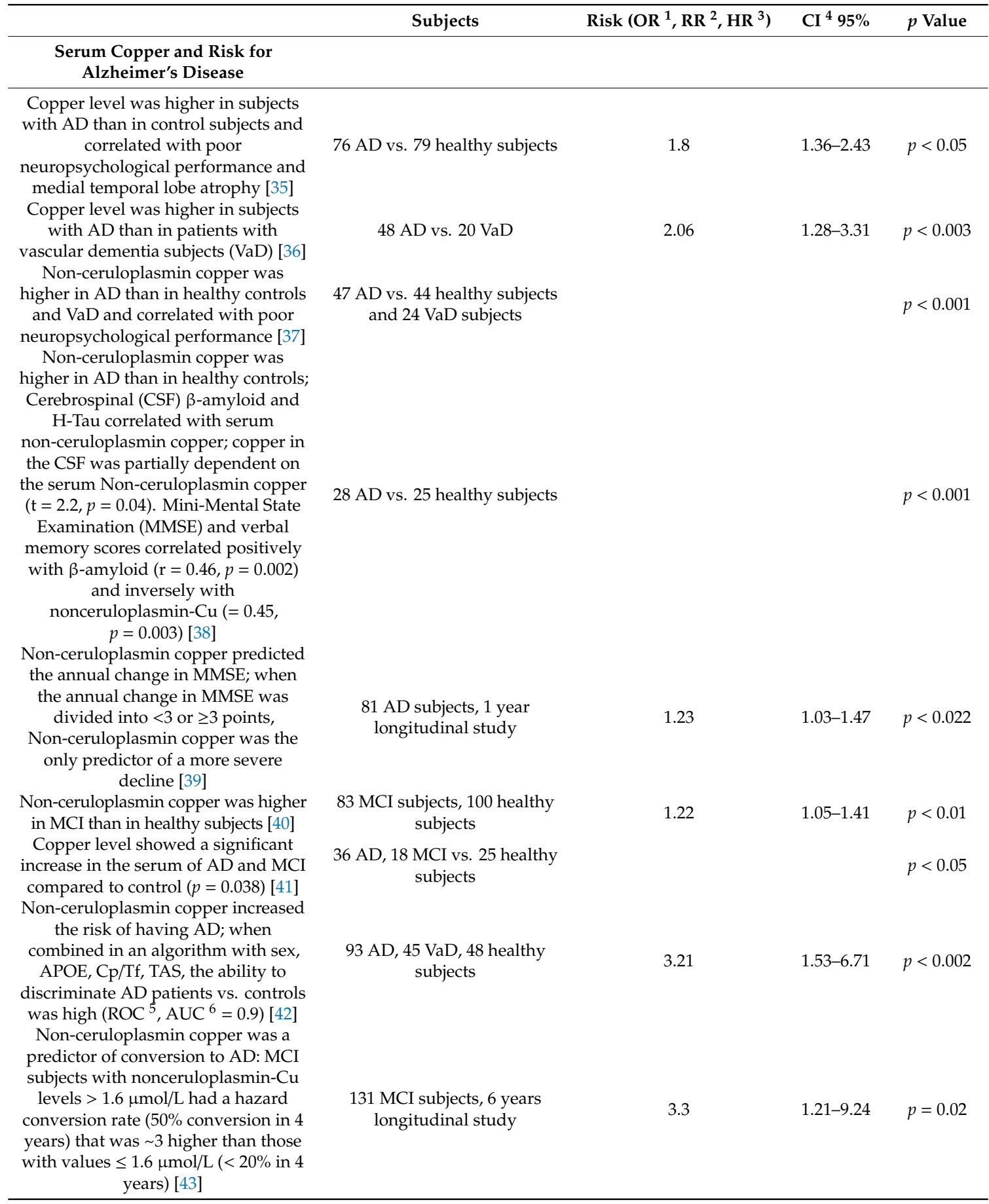


Table 1. Cont.

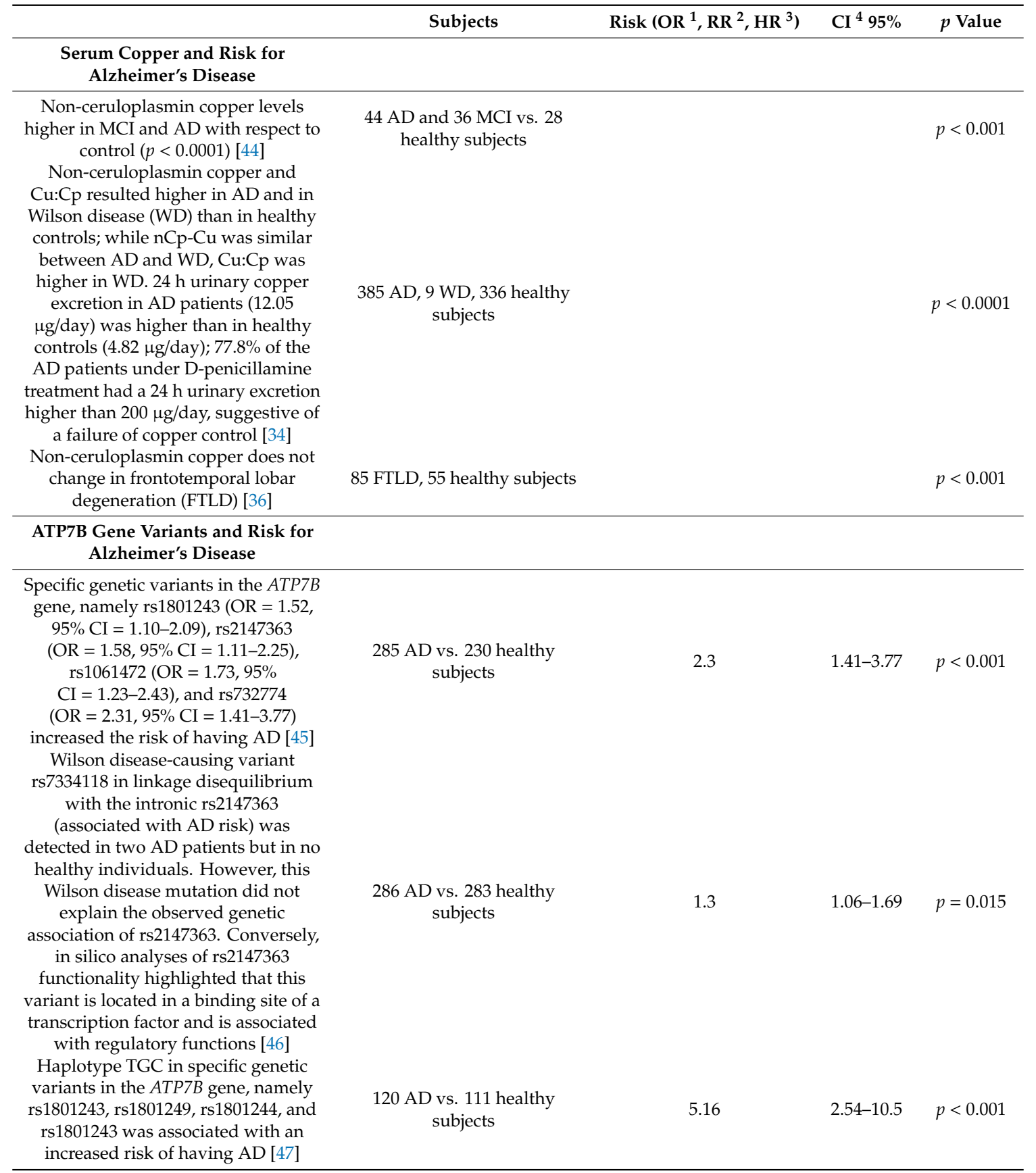

${ }^{1} \mathrm{OR}$, odds ratio; ${ }^{2} \mathrm{RR}$, relative risk; ${ }^{3} \mathrm{HR}$, hazard ratio; ${ }^{4} \mathrm{CI}$, Coefficient Interval; ${ }^{5} \mathrm{ROC}$, receiver operating characteristic curves depict the likelihood of a given test to be excellent, good, or worthless. The accuracy of the test depends, in this case, on the probability that a subject randomly selected from AD group has a nonceruloplasmin copper value higher than that of a subject randomly selected from the healthy control group. The accuracy is measured by the ${ }^{6}$ AUC (area under the curve) of the ROC curve. An AUC $=1$ represents a perfect test, a value of 0.5 represents a worthless test, and values in the $0.7-0.8$ range are considered to be fair.

Clinical studies also provided evidence of copper association with the severity of the disease in terms of performance in neuropsychological test batteries $[38,48]$, disease stage $[35,40,43,44]$ and electroencephalography (EEG) brain rhythms alterations, atrophic and cerebrovascular burden $[16,49]$.

In the AD brain, the progressive increase of the labile copper pool is consistent with the parallel presence of an expanded pool of non-ceruloplasmin copper in the blood [38,50]. Copper disturbance in $\mathrm{AD}$ can be described by a loss of functional copper from protein-bound pools that reduces energy production and oxidative stress control, and a gain of redox-toxic function that is described by a bigger 
pool of copper loosely bound to proteins [16]. Non-ceruloplasmin copper increases the susceptibility to AD approximately threefold [42,43] and it is also associated with a higher frequency of specific variants of the ATP7B gene [45-47,51-61] (Table 1). The gene variants rs1061472 and rs732774 of ATP7B are single nucleotide polymorphisms (SNPs) that modify properties of ATPase7B protein and are associated with a higher risk of $\mathrm{AD}$ and with the presence of a higher fraction of non-ceruloplasmin copper in serum $[38,55,58]$.

\subsection{Copper Connection with Alzheimer's Disease: Neuroscience}

Several scientific articles evaluating measurements of electrical activities in cell culture models have been included in this category $[17,62]$. A bulk of evidence in this category comes from studies in experimental models focused on the investigation of the causative correlation of copper and non-ceruloplasmin copper in AD development and progression (Table 2) $[63,64]$.

Table 2. Experimental models focused on the investigation of the causative correlation of copper and non-ceruloplasmin copper in Alzheimer's disease (AD) development and progression.

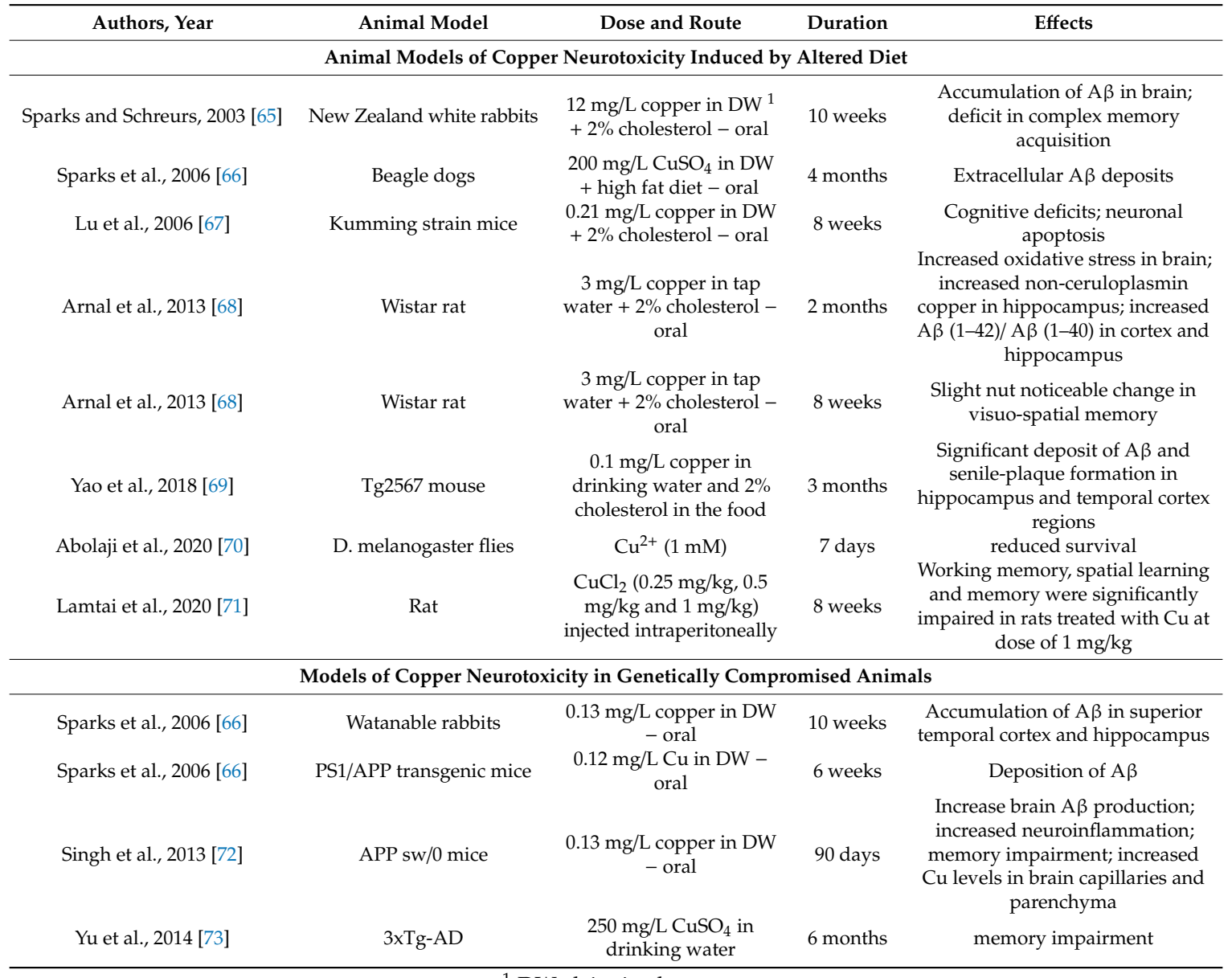

${ }^{1} \mathrm{DW}$, deionized water.

Huat et al. [74], in a recent review, stated that "considering the robust evidence for copper's essential roles in the brain, it is not surprising that many studies have proposed that an imbalance in its homeostasis is associated with neurodegenerative disorders".

In a seminal study published in 2003, Sparks and Schreurs demonstrated that in a cholesterol-fed rabbit model of $\mathrm{AD}$, adding trace amounts of $0.12 \mathrm{mg} / \mathrm{L}$ copper to distilled drinking water resulted in significantly enhanced cognitive waning. It also exacerbated $A \beta$ plaque deposition to that of control animals [65]. The study by Singh et al. provided a specific emphasis on the causative role 
that non-ceruloplasmin copper might play in AD onset and progression [72]. Singh et al. [72] studied normal mice (wild type) and a mouse model of AD (A $\beta P P$ transgenic mice) exposed to $0.13 \mathrm{mg} / \mathrm{L}$ of copper sulfate for 90 days levels of copper via drinking water, which doubled plasma concentrations of non-ceruloplasmin copper. This fact caused either a reduction of CSF A $\beta$ clearance across the blood brain barrier in wild-type mice or an identical effect, along with an increase in $\mathrm{A} \beta$ production in the transgenic mice. Thus, proposing the concept that non-ceruloplasmin copper is a causative risk factor for AD.

Thus, the relationship between copper and AD has been extensively researched in recent years.

Chronic exposure to copper and its dyshomeostasis has been linked to accelerate cognitive decline and potentially to increase the risk of $\operatorname{AD}[17,34,75]$. However, copper ions due to their redox ability have been considered to be the main potential therapeutic targets in AD, and a considerable number of ligands have been developed in order to modulate the toxicity associated with copper in this context, via disruption of the $\mathrm{A} \beta$-copper interaction [76].

\section{Use of Copper in Agriculture}

\subsection{Copper Used in Plant Disease Management}

Copper has been used in agriculture as a fertilizer and in the management of plant diseases. Organic agriculture is very dependent on copper as a fungicide. Several fungicides have copper in their formulation. The first fungicide to be used in all cropping systems worldwide and most famous there is the Bordeaux mixture $\left(25 \% \mathrm{CuSO}_{4}\right)$. The Bordeaux mixture and, consequently, copper has been used in agriculture for more than 160 years in the management of plant diseases [77]. Fishel [78] stated that, during the 1850s in the Bordeaux region in France, a vineyard farmer was having trouble with people stealing grapes from his vines. He applied a mixture of copper and lime to part of his vineyards to make the grapes unattractive. The result was that in the plants where the copper-lime mix was applied, there was no plant disease incidence.

Nowadays copper is mostly used to control the following plant diseases: Grape downy mildew, caused by the Plasmopara viticola, which is a highly damaging disease for grapes, particularly in oceanic climates; Apple scab, caused by the Venturia inaequalis; Potato late blight, caused by the Phytophthora infestans, responsible for a severe disease affecting potato production. In tropical regions, there is an occurrence of the Coffee Rust Disease caused by Hemileia vastatri and the cocoa Witches' Broom Disease, caused by Crinipellis perniciosa [79-81].

The Bordeaux mixture is widely used in organic agriculture worldwide since it is considered to have low toxicity for humans and the environment. Also, other fungicides containing copper in the forms of hydroxide, oxychloride, oxide, and octanoate, can be used in Organic Agriculture. However, they need authorization from the certifiers of organic products to minimize the accumulation of copper in the soil [82]. In Brazil, the recommendation follows specific legislation similar to that proposed by FAO [83-85].

In Europe, during the 1950s, copper in quantities of 20 to $30 \mathrm{~kg} \mathrm{ha}^{-1} \mathrm{year}^{-1}$, and sometimes even more than $80 \mathrm{~kg} \mathrm{ha}^{-1}$ year $^{-1}$, was applied to crops to protect the plants. In Germany, between 2010 and 2015, on average, in organic farming of hops, grapes, potatoes, apples, squash, and pears copper amounting to $3.1,2.2,1.5,1.5,1.4$, and $1.3 \mathrm{~kg} \mathrm{ha}^{-1} \mathrm{yr}^{-1}$, respectively, was used. In that country, the application of copper is restricted to $3 \mathrm{~kg} \mathrm{ha}^{-1} \mathrm{yr}^{-1}\left(4 \mathrm{~kg} \mathrm{ha}^{-1} \mathrm{yr}^{-1}\right.$ for hops) [86]. In 2013, a survey investigating copper use in Germany [87] revealed that the amounts of copper used per hectare in conventional grape $\left(0.8 \mathrm{~kg} \mathrm{ha}^{-1}\right)$, hop $\left(1.7 \mathrm{~kg} \mathrm{ha}^{-1}\right)$, and potato-farming $\left(0.8 \mathrm{~kg} \mathrm{ha}^{-1}\right)$ were well below those used in organic farming for the same crops $\left(2.3,2.6\right.$, and $1.4 \mathrm{~kg} \mathrm{ha}^{-1}$, respectively).

The United States Department of Agriculture (USDA) [88] included several copper-based substances in 'The National List of Allowed and Prohibited Substances' in organic agriculture in the United States of America (USA). For instance, copper sulfate is as an algicide in aquatic rice systems and used as tadpole shrimp control in aquatic rice production. Its application is limited to one 
application per field during any 24 months, and application rates are limited to those which do not increase baseline soil test values for copper over a timeframe agreed upon by the producer and the accredited certifying agent. The USA's legislation indicates that copper-based materials must be used in a manner that minimizes accumulation in the soil and shall not be used as herbicides.

According to Brazilian law [83-85] and FAO recommendation [82], the maximum amount of copper to be applied in organic agriculture is $6 \mathrm{~kg} \mathrm{ha}^{-1} \mathrm{yr}^{-1}$. According to Motta [89], in Brazil, some certifiers limit the use of the element to $3 \mathrm{~kg} \mathrm{ha}^{-1} \mathrm{yr}^{-1}$. On the other hand, in East Africa, $8 \mathrm{~kg} \mathrm{ha}^{-1} \mathrm{yr}^{-1}$ is the maximum allowed the annual copper application in areas with organic agriculture [90,91].

Formulation of Bordeaux mixture, for use in fruit trees, contains $2-10 \mathrm{~g} / \mathrm{L}$ of copper sulfate and the same amount of lime $\left(\mathrm{Ca}(\mathrm{OH})_{2}\right)$ diluted in water. The application is sprayed from the vegetative phase until the fruit maturation, with intervals of 10 to 15 days between applications [92]. Natural adhesive spreaders, such as sugar (10-15 g) or skim milk (200 mL), can be used for better adherence to plant leaves [89].

For the grapevine, for example, there is no fixed volume of Bordeaux mixture to be used per hectare, which can vary between 150-700 $\mathrm{L} \mathrm{ha}^{-1}$. This volume varies according to several factors, such as the type of sprayer, the size of the plants, the distance between rows of plants, the climatic conditions, the disease to be controlled, and the vegetative stage of the plant [93]. Thus, considering that the smallest application volume $\left(150 \mathrm{~L} \mathrm{ha}^{-1}\right)$ has the highest copper content $(10 \mathrm{~g} / \mathrm{L})$, the highest volume (700 L ha $\left.{ }^{-1}\right)$ and the lowest content $(2 \mathrm{~g} / \mathrm{L})$, a maximum of 16 applications per year can be performed in Brazil, so that the maximum annual copper dose of $6 \mathrm{~kg} \mathrm{ha}^{-1} \mathrm{yr}^{-1}$ is not exceeded, as recommended by FAO [82].

\subsection{Copper Accumulation in Soil and Water}

In general, the copper ion is very immobile in soil. Therefore, continuous copper spraying results in the accumulation of this element in the topsoil, reaching toxic levels, possibly causing plant stress, decreasing the soil microbiota biodiversity, and reducing soil fertility [94-96]. That is the main reason why organic farmers try to minimize copper use [86].

Sacristán and Carbó [97] studied Spanish and Australian agricultural soils cropped with lettuce. They found that soils with higher $\mathrm{pH}$ and higher levels of organic matter and clay result in lower copper mobility in-depth, and therefore copper accumulates in the topsoil layers. However, in general, the toxic effect of copper in plants increases as $\mathrm{pH}$ values decrease, due to a rise in the copper bioavailability. On the other hand, in a study conducted in an agricultural region of Haining County in southeast China, Wu et al. [98] found that the copper availability ratio and available copper concentration were decreased as a function of decreasing $\mathrm{pH}$ in acid soils $(\mathrm{pH}<6.5)$, and increased with increasing $\mathrm{pH}$ in alkali soils ( $\mathrm{pH}>7.5$ ). In Chile, Ávila et al. [99] found that copper toxicity for earthworms was lower in soils with a higher than $3.5 \%$ organic matter (OM) content, likely due to the change in bioavailable copper ions. The mitigating effect of OM was exact for soils with up to $500 \mathrm{mg} \mathrm{kg}^{-1}$ of copper.

The copper exists in soils mainly $(60 \%)$ water soluble, exchangeable and sorbed forms of total copper in the upper part of soil profiles and the percentage decreases with increasing depth [100]. In Australia, total copper content in soil of Victorian vineyards is five to fifty times as high as that found in natural soils. Moreover, copper content in soil decreases with increasing distance from vines [100].

Soil copper concentration of $100 \mathrm{mg} \mathrm{kg}^{-1}$ influences rice growth, and $10 \%$ or more of grain yield, straw weight, and root weight were lost [101]. Besides copper use for plant protection, the use of pig slurry can contribute to copper accumulation in the soil. The tillage system determines the distribution of copper in the soil layers and can be used as a tool to avoid accumulation in the topsoil [102].

Copper release into water occurs through soil erosion, industrial discharge, sewage-treatment, and antifouling paints. Thus, erosion of soils that contain soil particles with adsorbed copper can result in increased copper concentrations in rivers and lakes [103]. Certainly, there is generally no contamination of the groundwater table due to copper applications in agriculture. Copper has a low mobility in the soil and its mobility decreases with increasing clay or organic matter content [97]. 
At present, the main concern is the increase of copper content during the distribution of drinking water, because many pipes and plumbing fixtures contain copper, which can leach into the drinking water [103]. Certainly in the last few years the use of PVC pipes instead of copper pipes has reduced the concentration of copper in the water. However, this is a problem that still persists in old houses that have copper plumbing for heated water, because this water is often used to cook food.

\section{Agricultural Use to Copper and Its Link to Alzheimer's Disease}

Shen et al. [104] showed that the prevalence of AD in the regions in Mainland China with the highest soil copper contents $\left(60-80 \mathrm{mg} \mathrm{kg}^{-1}\right)$ reached 2.6 times compared to the regions that had the lowest copper contents $\left(20-40 \mathrm{mg} \mathrm{kg}^{-1}\right)$.

Morris et al. [105] evaluated 3718 Chicago residents with 65 years and older. They verified that high dietary intake of copper in conjunction with a diet high in saturated and trans fats might be associated with accelerated cognitive decline. Brewer [75] proposed that copper bivalent $\left(\mathrm{Cu}^{2+}\right)$ ingestion is a major new environmental risk factor for AD. This author commented that $\mathrm{Cu}^{2+}$ is mainly abundant in water and food supplement pills and is much more damaging to cognition. The question remains how much and through which pathways copper used in agriculture ends up in the human diet. Copper is applied on the vegetation and only a small part is absorbed by the leaves and fruits and translocated in the plant. Copper reaches the soil where it is immobilized mainly by soil organic matter and clay particles. Plant roots take up copper as well.

The European Food Safety Authority (EFSA) report [106] makes reference to studies claiming that plants never take up more copper then the nutritional amount needed. However, this is in sharp contrast with other studies carried out in the field of phytoremediation, showing that arable and vegetable crops can take up much more copper then needed and allocate this to root, shoot and fruit tissue. By removal of the biomass, sites can be cleaned from heavy metal and copper pollution [107]. When using crops, it is relevant to know in which plant tissues copper accumulates. Tomato fruit and roots were very effective and in this case fruits should not be used for consumption [107]. Another study showed that Amaranthus, Indian Mustard and Sunflower shoot tissue were able to take up two to four times higher copper amounts than the roots, especially in fertilized soils [108]. EFSA experts [106] further conclude that insufficient scientific studies are available to conclude on the amount of copper residues in some key crops like grapes, tomatoes and cucurbits cropped following the Good Agricultural Practices guidelines. Therefore, more research is needed to clarify how much copper in organic food is bivalent $\left(\mathrm{Cu}^{2+}\right)$.

Hummes et al. [109] evaluated the centenarian vineyard in the Pinto Bandeira municipality, the northeastern region of the state of Rio Grande do Sul, Brazil. The evaluated vines have been sprayed with copper for more than 100 years. Copper in root and leaf tissues reached 12,300 and $6800 \mathrm{mg} \mathrm{kg}^{-1}$, respectively. In grape juice and wine, copper was 9.08 and $0.78 \mathrm{mg} \mathrm{L}^{-1}$, respectively. However, copper levels in grape juice exceeded by $908 \%$ the limit established by Brazilian and international norms. On the other hand, Santos et al. [110] verified that the reduction in the copper content during the last stages of the wine cycle is related to its precipitation in the storage tanks. The copper content in the vineyard soils and, consequently, in grape must and wines is related to different factors such as the total amount of copper fungicide applied during the production period, the number of days between the last application and harvest, biological specificity of cultivars during growth, and the varietal characteristics [111].

Copper has a propensity for the accumulation in the root tissues with little upward movement towards shoots, fruits, and seeds [112]. Alexander et al. [113] verified that carrot and pea cultivars exhibited significant differences in the accumulation of copper from contaminated soil. That demonstrates that the utilization of cultivars that accumulate lower copper can yield better food.

Garrido and Botton [114] recommended a seven-day grace period (the period between the last application and the harvest) for spray products using copper in grape plants. When farmers use copper-oxychloride, the grace period is fourteen days for beans, and seven days for potato, eggplant, 
carrot, papaya, watermelon, peppers, and tomatoes [115]. We suggest that the grace period needs to be researched further because the copper residual contamination is dependent on the copper content in the spraying fungicide solution. Indeed, the new upper limits and recommendations of copper should be indicated in the future, due to its high impact on the soil, ecosystem, and human health.

\section{Human Health Risk Assessment Related to Copper Use in Agriculture}

The EFSA conducted a review about the pesticide risk assessment of the active substance of copper compounds [106]. That report points out the difficulties in replacing copper in plant disease management in organic agriculture. At the same time, it touches the relationship between copper and AD stating there is no scientific evidence for this, without citing any reference. However, there is evidence in numerous papers suggesting the existence of a relation between copper accumulation in the human body at aging in those individuals with a predisposition to copper metabolic abnormalities that can be identified by having higher than normal levels of non-ceruloplasmin copper and the relationship with AD development.

Massie et al. [116]; Zatta et al. [117]; Vasudevaraju et al. [118] indicated that copper accumulation is real in aging animals and the human body. However, more than the accumulation, it is the dislocation of copper as loosely bound copper also in the brain that can cause the toxicity [32]. When bound to proteins, copper is not toxic even though it increases. Conversely, when non-ceruloplasmin copper exceeds the normal reference range [116,117], it is toxic. Furthermore, recent studies showed that frequencies of the functional SNPs rs1061472 A > G and rs 732774 G > A, as well as frequency of the haplotype containing the derived GA risk alleles are associated with increased levels of non-ceruloplasmin copper and with an increased risk of AD [55] (Table 1). This evidence is in line with the EFSA statement and suggests that human carriers of $A T P 7 B$ functional SNPs [65] exhibit higher than normal values of non-ceruloplasmin copper and are therefore prone to a copper susceptibility that can increase the risk of developing AD.

Furthermore, Zatta et al. [117] evaluated the copper contents in young (8 months) and adult (9 to 12 years) bovine brains, verifying that the copper contents varied from 1.67 to $15.7 \mathrm{mg} \mathrm{g}^{-1}$ of fresh tissue, respectively, indicating that, with aging, there is an accumulation of copper in the brain. Copper accumulation with aging has also been demonstrated to occur in humans. Vasudevaraju et al. [118] categorized human brains into three groups. Group I: below 40 years, Group II: between 41 and 60 years, and Group III: above 60 years. They found that $\mathrm{Cu}$ and Fe contents are significantly elevated while $\mathrm{Zn}$ is significantly depleted as one progresses from Group I to Group III, indicating changes in $\mathrm{Cu}$ and Fe with aging in the frontal cortex and hippocampus. Furthermore, those authors found that the elevation of metals was higher in the frontal cortical region compared to the hippocampal region. As a matter of fact, Vanacore et al. [119] confirmed relationships between a high content of copper and a higher incidence of AD. As previously explained, copper is a nutrient to humans and participates in the composition of important proteins [120]. However, when excess non-ceruloplasmin copper generates, it can lead to oxidative stress and other harmful effects [121].

To confirm this statement, in addition to data reported in Tables 1 and 2, Hsu et al. [122] showed the environmental and dietary exposure to copper and its cellular mechanisms linking to AD. Moreover, Pal et al. [123] reported that autopsy of brains of AD-affected patients shows the presence of abnormally high contents of copper in the deposited $A \beta$ plaques, while a significantly higher level of copper was found in the serum of patients suffering from Type 2 Diabetes mellitus.

Based on the evidence produced by meta-analyses, large population studies, clinical and genetic as well as experimental in vitro and animal studies that we have summarized in this review paper, we think EFSA could make a bigger effort to provide an up-to-date overview about the possible causative link between disturbed copper homeostasis and AD pathology in humans. It is clear that copper use in agriculture is not the only source of excessive copper uptake in humans, but the existing evidence about the biological connection of copper imbalance to AD together with the toxic effect of copper on soil organisms mentioned earlier in this review, has reached such a critical mass that a 
government action is needed. We hope to stimulate supranational discussion about this topic to invest more in research with the aim to reduce the use of copper in agriculture and the risk of developing AD among those individuals with a predisposition to copper metabolic abnormalities while safeguarding the soil biological diversity and the agroecosystem functions they provide.

\section{Agroecological Strategies to Reduce the Use of Copper in Agriculture}

In the previous section of this paper, we have given an overview of the scientific evidence sustaining that excessive use of copper in agriculture that can lead to severe soil pollution. Through the food chain, copper may accumulate in the human body, causing health problems in those people with a predisposition to copper imbalance, as those carriers of the ATP7B functional SNPs rs1061472 A > G and rs $732774 \mathrm{G}>\mathrm{A}$ [53].

Since 2001, the European Union and its member states have financed a wide variety of projects aimed at decreasing the reliance on copper use, especially in organic agriculture [124]. In Germany, the Federal Program for Organic Farming and Other Forms of Sustainable Agriculture (BOLN) has provided substantial funding for research projects. Research efforts focused on the further development of resistant varieties and forecast models, improved cultivation techniques and spraying techniques, the introduction of new copper products with low copper contents, improvement of copper pesticide impact assessment, development and introduction of copper-free alternatives and implementation and optimization of overall plant protection strategies [87].

In organic viticulture in northern and southern Italy, reduced and conventional dosages of traditional copper solutions were compared against copper peptidase, a new solution that has a lower than standard copper concentration thanks to its increased capacity to penetrate the pathogen cell [125]. Unfortunately, also the phytotoxicity against the crop was high. A UK study [126] concluded, based on one-year data, that apple production was higher while apple scab (Venturia inaequalis) infestation was lower in apple trees in an agroforestry system compared to traditional orchard systems. This result may have implications for reduced copper dosages in agroforestry systems. In tomato, the dependency on copper in crop protection against Phytophthora infestans could be reduced by using low copper dosages. Other research efforts have concentrated on systematic testing of natural products, among which chitosan, against a wide variety of diseases as shown in a comprehensive review by La Torre et al. [124]. Some of these natural products, such as leaf licorice extract, Yucca schidigera Roezl ex Ortgies extract, or potassium hydrogen carbonate [127], were effective against tomato diseases thanks to the preventive activity and direct effect on mycelial growth and sporangia germination.

Besides the simple substitution of copper by other natural or synthetic products [125,127] or new copper solutions with similar efficacy but lower copper concentrations, agroecological approaches for the design of sustainable cropping systems need to be taken into consideration. In the first place, agroecological approaches would guarantee a detailed analysis of the cropping systems that depend on copper and take into account the specific socio-economical situation of the regional context. It would require a participatory approach involving farmers, local stakeholders, and the entire food system to determine potential solutions for a reduction or abandonment of copper applications. Agroecological solutions will be sought mainly in terms of prevention of the key disease problems in the specific cropping system. These solutions can be agronomic, but also the implementation of biodiversity-based solutions should be explored in more detail. The apple-agroforestry case study mentioned before is a good example of such an approach. The enhancement of functional biodiversity in the cropping systems aimed at the prevention and control of these key diseases can follow the approach proposed by Moonen and Bàrberi [128]. This approach foresees in the first place an analysis, preferably in a participatory-action research context, of strengths and weaknesses of the cropping system and its socio-economical context concerning the specific problem (in this case, the need to reduce reliance on copper). This first analysis will result in the definition of prioritized ecosystem services and trade-offs to be avoided (in this case, the agroecosystem services needed are disease control without copper). Experts (in this case, mainly plant pathologists and agronomists) need to identify one or 
more functional groups, defined as 'clusters of elements (at gene, species, or habitat level) that provide the same agroecosystem service' [128] that can provide the desired agroecosystem services while maintaining crop production. Based on this knowledge, the cropping system can be redesigned through participatory action research.

In support to this biodiversity-based redesign of the cropping system aimed at disease control, farmers need to consider agronomical solutions to reduce the dependency of plant protection products (PPPs) by optimization and increased use of preventive measures like cultural measures and non-chemical plant protection as suggested by IFOAM EU GROUP [86]. For example, in annual and horticultural cropping systems, crop rotations are effective in disease control, as shown by Bankina et al. [129]. They reported a significant decrease in wheat stem rot disease in diversified crop rotations. Also, the use of cover crops can be considered to diversify crop rotation and break diseases. However, disease control is effective in the early crop stage but does not last until crop harvest, as shown by Runno-Paurson et al. [130] for potato blight control in organic agriculture. Diversified crop rotations are especially relevant for disease control in conservation agriculture or reduced tillage systems since these systems are more susceptible to disease development, such as Fusarium blight in winter cereals [131]. Other agronomic interventions that can greatly affect disease development are optimization of irrigation systems as shown by Lage et al. [132] controlling powdery mildew in organic tomato production, and the selection and development of resistant or robust varieties [124]. Not much research was performed on herbaceous vegetation management for disease control in orchards and vineyards, but some studies showed that the choice of vegetation type is relevant. For example, some vegetation types were able to reduce Phytophthora crown or root rot in apple orchards [133]. At the same time, exotic grasses improved black foot pathogens such as Ilyonectria liriodendri in vineyards through alteration of the root-associated fungal communities in vineyards [134]. Also, optimization of air movement in the crop canopy through correct pruning strategies are effective [135] or in high-value crops netting can be used to optimize the microclimate, protect the crop from late frost and hail damage and therefore reduce copper-based treatments in organic agriculture [124].

Despite the evidence showing that copper causes severe damage to agroecosystems and human health and despite the effort made already to show alternatives for copper use in organic farming, in Europe, where the Current Authorization of Copper-based Antimicrobial Compounds [136] expired on 31 January 2019, no decision has been made yet [137].

Lamichhane et al. [77] commented that the formulation of appropriate policies aimed at the reduction of the risks associated with copper represents a key challenge for researchers, policymakers, and farmers soon.

\section{Conclusions}

Copper is mostly used to control plant diseases. The Bordeaux mixture (copper sulfate) is widely used in organic agriculture worldwide since it is considered to have low toxicity for humans and the environment. However, when in excess, copper can lead to oxidative stress and other harmful effects in humans with a predisposition to copper imbalance. Chronic exposure to copper in people susceptible to copper dyshomeostasis, as revealed by higher than normal levels of non-ceruloplasmin copper, has been linked to accelerated cognitive decline and an increased risk of AD.

Besides the adoption of strategies for the minimization of copper in organic farming such as the use of natural alternatives, lower application rates and the reduction of the dependency of plant protection products by optimization and increased use of preventive measures like cultural measures and non-chemical plant protection, the application of agroecological approaches for the design of sustainable cropping systems needs to be taken into consideration.

Funding: This research received no external funding but the review was performed during the visiting period of F.C.C. at the Land Lab of Scuola Superiore Sant'Anna, Pisa, Italy.

Conflicts of Interest: R.S. is Chief Scientific Officer and has some shares in IGEA Pharma N.V.; other authors declare no commercial or noncommercial conflicts of interest relating to this work. 


\section{References}

1. WHO|Disease Burden and Mortality Estimates. Available online: http://origin.who.int/healthinfo/global_ burden_disease/estimates/en/ (accessed on 6 May 2020).

2. Hardy, J.; Selkoe, D.J. The amyloid hypothesis of Alzheimer's disease: Progress and problems on the road to therapeutics. Science 2002, 297, 353-356. [CrossRef]

3. Masters, C.L.; Selkoe, D.J. Biochemistry of amyloid beta-protein and amyloid deposits in Alzheimer disease. Cold Spring Harb. Perspect. Med. 2012, 2, a006262. [CrossRef] [PubMed]

4. Goedert, M.; Spillantini, M.G. A century of Alzheimer's disease. Science 2006, 314, 777-781. [CrossRef]

5. Alzheimer's Association, Alzheimer's disease facts and figures. Alzheimer's Dement. 2019, 15, 321-387.

6. Schneider, L.S.; Mangialasche, F.; Andreasen, N.; Feldman, H.; Giacobini, E.; Jones, R.; Mantua, V.; Mecocci, P.; Pani, L.; Winblad, B.; et al. Clinical trials and late-stage drug development for Alzheimer's disease: An appraisal from 1984 to 2014. J. Intern. Med. 2014, 275, 251-283. [CrossRef] [PubMed]

7. Exposure, Exposure, Exposure? At CTAD, Aducanumab Scientists Make a Case I ALZFORUM. Available online: https://www.alzforum.org/news/conference-coverage/exposure-exposure-exposure-ctadaducanumab-scientists-make-case (accessed on 4 May 2020).

8. Zegers, I.; Beetham, R.; Keller, T.; Sheldon, J.; Bullock, D.; MacKenzie, F.; Trapmann, S.; Emons, H.; Schimmel, $\mathrm{H}$. The importance of commutability of reference materials used as calibrators: The example of ceruloplasmin. Clin. Chem. 2013, 59, 1322-1329. [CrossRef]

9. Vos, S.J.B.; van Boxtel, M.P.J.; Schiepers, O.J.G.; Deckers, K.; Vugt, M.; Carriere, I.; Dartigues, J.F.; Peres, K.; Artero, S.; Ritchie, K.; et al. Modifiable Risk Factors for Prevention of Dementia in Midlife, Late Life and the Oldest-Old: Validation of the LIBRA Index. J. Alzheimer's Dis. 2017, 58, 537-547. [CrossRef]

10. Schiepers, O.J.G.; Kohler, S.; Deckers, K.; Irving, K.; O’Donnell, C.A.; van den Akker, M.; Verhey, F.R.J.; Vos, S.J.B.; Vugt, M.E.; van Boxtel, M.P.J. Lifestyle for Brain Health (LIBRA): A new model for dementia prevention. Int. J. Geriatr. Psychiatry 2018, 33, 167-175. [CrossRef] [PubMed]

11. Deckers, K.; Barbera, M.; Kohler, S.; Ngandu, T.; van Boxtel, M.; Rusanen, M.; Laatikainen, T.; Verhey, F.; Soininen, H.; Kivipelto, M.; et al. Long-term dementia risk prediction by the LIBRA score: A 30-year follow-up of the CAIDE study. Int. J. Geriatr. Psychiatry 2020, 35, 195-203. [CrossRef] [PubMed]

12. Barnard, N.D.; Bush, A.I.; Ceccarelli, A.; Cooper, J.; Jager, C.A.; Erickson, K.I.; Fraser, G.; Kesler, S.; Levin, S.; Lucey, M.B.; et al. Dietary and lifestyle guidelines for the prevention of Alzheimer's disease. Neurobiol. Aging 2014, 35, 74-78. [CrossRef] [PubMed]

13. Rosenberg, A.; Ngandu, T.; Rusanen, M.; Antikainen, R.; Backman, L.; Havulinna, S.; Hanninen, T.; Laatikainen, T.; Lehtisalo, J.; Levalahti, E. Multidomain lifestyle intervention benefits a large elderly population at risk for cognitive decline and dementia regardless of baseline characteristics: The FINGER trial. Alzheimer's Dement. 2018, 14, 263-270. [CrossRef] [PubMed]

14. Licher, S.; Ahmad, S.; Karamujic-Comic, H.; Voortman, T.; Leening, M.J.G.; Ikram, M.A.; Ikram, K. Genetic predisposition, modifiable-risk-factor profile and long-term dementia risk in the general population. Nat. Med. 2019, 25, 1364-1369. [CrossRef] [PubMed]

15. Multhaup, G.; Schlicksupp, A.; Hesse, L.; Beher, D.; Ruppert, T.; Masters, C.L.; Beyreuther, K. The amyloid precursor protein of Alzheimer's disease in the reduction of copper (II) to copper (I). Science 1996, 271, 1406-1409. [CrossRef] [PubMed]

16. Kepp, K.P.; Squitti, R. Copper imbalance in Alzheimer's disease: Convergence of the chemistry and the clinic. Coord. Chem. Rev. 2019, 397, 168-187. [CrossRef]

17. Squitti, R.; Malosio, M.L.; Rongioletti, M.C.A.; Tecchio, F. Copper involvement in glutamatergic transmission in physiology and disease as revealed by magnetoencephalography/electroencephalography (MEG/EEG) studies. Aging Clin. Exp. Res. 2019, 9. [CrossRef] [PubMed]

18. Sensi, S.L.; Granzotto, A.; Siotto, M.; Squitti, R. Copper and Zinc Dysregulation in Alzheimer's Disease. Trends Pharmacol. Sci. 2018, 39, 1049-1063. [CrossRef] [PubMed]

19. Acevedo, K.M.; Hung, Y.H.; Dalziel, A.H.; Li, Q.X.; Laughton, K.; Wikhe, K.; Rembach, A.; Roberts, B.; Masters, C.L.; Bush, A.I.; et al. Copper promotes the trafficking of the amyloid precursor protein. J. Biol. Chem. 2011, 286, 8252-8262. [CrossRef] 
20. Atwood, C.S.; Scarpa, R.C.; Huang, X.; Moir, R.D.; Jones, W.D.; Fairlie, D.P.; Tanzi, R.E.; Ashley, I. Bush Characterization of copper interactions with alzheimer amyloid beta peptides: Identification of an attomolar-affinity copper binding site on amyloid beta1-42. J. Neurochem. 2000, 75, 1219-1233. [CrossRef]

21. Huang, X.; Atwood, C.S.; Hartshorn, M.A.; Multhaup, G.; Goldstein, L.E.; Scarpa, R.C.; Cuajungco, M.P.; Gray, D.N.; Lim, J.; Moir, R.D.; et al. The A beta peptide of Alzheimer's disease directly produces hydrogen peroxide through metal ion reduction. Biochemistry 1999, 38, 7609-7616. [CrossRef]

22. Huang, X.; Cuajungco, M.P.; Atwood, C.S.; Hartshorn, M.A.; Tyndall, J.D.A.; Hanson, G.R.; Stokes, K.C.; Leopold, M.; Multhaup, G.; Goldstein, L.E.; et al. Cu(II) potentiation of Alzheimer abeta neurotoxicity. Correlation with cell-free hydrogen peroxide production and metal reduction. J. Biol. Chem. 1999, 274, 37111-37116. [CrossRef]

23. Palmer, C.; Menzies, S.L.; Roberts, R.L.; Pavlick, G.; Connor, J.R. Changes in iron histochemistry after hypoxic-ischemic brain injury in the neonatal rat. J. Neurosci. Res. 1999, 56, 60-71. [CrossRef]

24. Cherny, R.A.; Legg, J.T.; McLean, C.A.; Fairlie, D.P.; Huang, X.; Atwood, C.S.; Beyreuther, K.; Tanzi, R.E.; Masters, C.L.; Bush, A.I. Aqueous dissolution of Alzheimer's disease Abeta amyloid deposits by biometal depletion. J. Biol. Chem. 1999, 274, 23223-23228. [CrossRef] [PubMed]

25. Cherny, R.A.; Atwood, C.S.; Xilinas, M.E.; Gray, D.N.; Jones, W.D.; McLean, C.A.; Barnham, K.J.; Volitakis, I.; Fraser, F.W.; Kim, Y.; et al. Treatment with a copper-zinc chelator markedly and rapidly inhibits beta-amyloid accumulation in Alzheimer's disease transgenic mice. Neuron 2001, 30, 665-676. [CrossRef]

26. Atwood, C.S.; Moir, R.D.; Huang, X.; Scarpa, R.C.; Bacarra, N.M.; Romano, D.M.; Hartshorn, M.A.; Tanzi, R.E.; Bush, A.I. Dramatic aggregation of Alzheimer abeta by $\mathrm{Cu}(\mathrm{II})$ is induced by conditions representing physiological acidosis. J. Biol. Chem. 1998, 273, 12817-12826. [CrossRef] [PubMed]

27. Barnham, K.J.; Bush, A.I. Metals in Alzheimer's and Parkinson's diseases. Curr. Opin. Chem. Biol. 2008, 12, 222-228. [CrossRef] [PubMed]

28. Bucossi, S.; Ventriglia, M.; Panetta, V.; Salustri, C.; Pasqualetti, P.; Mariani, S.; Siotto, M.; Rossini, P.M.; Squitti, R. Copper in Alzheimer's disease: A meta-analysis of serum, plasma, and cerebrospinal fluid studies. J. Alzheimer's Dis. 2011, 24, 175-185. [CrossRef]

29. Squitti, R.; Simonelli, I.; Ventriglia, M.; Siotto, M.; Pasqualetti, P.; Rembach, A.; Doecke, J.; Bush, A.I. Meta-analysis of serum non-ceruloplasmin copper in Alzheimer's disease. J. Alzheimer's Dis. 2014, 38, 809-822. [CrossRef]

30. Li, D.D.; Zhang, W.; Wang, Z.Y.; Zhao, P. Serum Copper, Zinc, and Iron Levels in Patients with Alzheimer's Disease: A Meta-Analysis of Case-Control Studies. Front. Aging Neurosci. 2017, 9, 300. [CrossRef] [PubMed]

31. Schrag, M.; Mueller, C.; Oyoyo, U.; Smith, M.A.; Kirsch, W.M. Iron, zinc and copper in the Alzheimer's disease brain: A quantitative meta-analysis. Some insight on the influence of citation bias on scientific opinion. Prog. Neurobiol. 2011, 94, 296-306. [CrossRef]

32. Ventriglia, M.; Bucossi, S.; Panetta, V.; Squitti, R. Copper in Alzheimer's disease: A meta-analysis of serum, plasma, and cerebrospinal fluid studies. J. Alzheimer's Dis. 2012, 30, 981-984. [CrossRef]

33. Wang, Z.X.; Tan, L.; Wang, H.F.; Ma, J.; Liu, J.; Tan, M.S.; Sun, J.H.; Zhu, X.C.; Jiang, T.; Yu, J.T. Serum Iron, Zinc, and Copper Levels in Patients with Alzheimer's Disease: A Replication Study and Meta-Analyses. J. Alzheimer's Dis. 2015, 47, 565-581. [CrossRef] [PubMed]

34. Squitti, R.; Ghidoni, R.; Simonelli, I.; Ivanova, I.D.; Colabufo, N.A.; Zuin, M.; Benussi, L.; Binetti, G.; Cassetta, E.; Rongioletti, M.; et al. Copper dyshomeostasis in Wilson disease and Alzheimer's disease as shown by serum and urine copper indicators. J. Trace Elem. Med. Biol. 2018, 45, 181-188. [CrossRef] [PubMed]

35. Squitti, R.; Lupoi, D.; Pasqualetti, P.; Dal Forno, G.; Vernieri, F.; Chiovenda, P.; Rossi, L.; Cortesi, M.; Cassetta, E.; Rossini, P.M. Elevation of serum copper levels in Alzheimer's disease. Neurology 2002, 59, 1153-1161. [CrossRef] [PubMed]

36. Squitti, R.; Fostinelli, S.; Siotto, M.; Ferrari, C.; Binetti, G.; Benussi, L.; Rongioletti, M.; Ghidoni, R. Serum Copper is not Altered in Frontotemporal Lobar Degeneration. J. Alzheimer's Dis. 2018, 63, 1427-1432. [CrossRef] [PubMed]

37. Squitti, R.; Pasqualetti, P.; Dal Forno, G.; Moffa, F.; Cassetta, E.; Lupoi, D.; Vernieri, F.; Rossi, L.; Baldassini, M.; Rossini, P.M. Excess of serum copper not related to ceruloplasmin in Alzheimer disease. Neurology 2005, 64, 1040-1046. [CrossRef] [PubMed] 
38. Squitti, R.; Barbati, G.; Rossi, L.; Ventriglia, M.; Dal Forno, G.; Cesaretti, S.; Moffa, F.; Caridi, I.; Cassetta, E.; Pasqualetti, P.; et al. Excess of nonceruloplasmin serum copper in AD correlates with MMSE, CSF [beta]-amyloid, and h-tau. Neurology 2006, 67, 76-82. [CrossRef]

39. Squitti, R.; Bressi, F.; Pasqualetti, P.; Bonomini, C.; Ghidoni, R.; Binetti, G.; Cassetta, E.; Moffa, F.; Ventriglia, M.; Vernieri, F.; et al. Longitudinal prognostic value of serum "free" copper in patients with Alzheimer disease. Neurology 2009, 72, 50-55. [CrossRef] [PubMed]

40. Squitti, R.; Ghidoni, R.; Scrascia, F.; Benussi, L.; Panetta, V.; Pasqualetti, P.; Moffa, F.; Bernardini, S.; Ventriglia, M.; Binetti, G.; et al. Free copper distinguishes mild cognitive impairment subjects from healthy elderly individuals. J. Alzheimer's Dis. 2011, 23, 239-248. [CrossRef] [PubMed]

41. Lopez, N.; Tormo, C.; De Blas, I.; Llinares, I.; Alom, J. Oxidative stress in Alzheimer's disease and mild cognitive impairment with high sensitivity and specificity. J. Alzheimer's Dis. 2013, 33, 823-829. [CrossRef]

42. Squitti, R.; Pasqualetti, P.; Polimanti, R.; Salustri, C.; Moffa, F.; Cassetta, E.; Lupoi, D.; Ventriglia, M.; Cortesi, M.; Siotto, M.; et al. Metal-score as a potential non-invasive diagnostic test for Alzheimer's disease. Curr. Alzheimer Res. 2013, 10, 191-198. [CrossRef]

43. Squitti, R.; Ghidoni, R.; Siotto, M.; Ventriglia, M.; Benussi, L.; Paterlini, A.; Magri, M.; Binetti, G.; Cassetta, E.; Caprara, D.; et al. Value of serum nonceruloplasmin copper for prediction of mild cognitive impairment conversion to Alzheimer disease. Ann. Neurol. 2014, 75, 574-580. [CrossRef] [PubMed]

44. Rozzini, L.; Lanfranchi, F.; Pilotto, A.; Catalani, S.; Gilberti, M.E.; Paganelli, M.; Apostoli, P.; Padovani, A. Serum Non-Ceruloplasmin Non-Albumin Copper Elevation in Mild Cognitive Impairment and Dementia due to Alzheimer's Disease: A Case Control Study. J. Alzheimer's Dis. 2018, 61, 907-912. [CrossRef] [PubMed]

45. Squitti, R.; Polimanti, R.; Bucossi, S.; Ventriglia, M.; Mariani, S.; Manfellotto, D.; Vernieri, F.; Cassetta, E.; Ursini, F.; Rossini, P.M. Linkage disequilibrium and haplotype analysis of the ATP7B gene in Alzheimer's disease. Rejuvenation Res. 2013, 16, 3-10. [CrossRef] [PubMed]

46. Bucossi, S.; Polimanti, R.; Ventriglia, M.; Mariani, S.; Siotto, M.; Ursini, F.; Trotta, L.; Scrascia, F.; Callea, A.; Vernieri, F.; et al. Intronic rs2147363 variant in ATP7B transcription factor-binding site associated with Alzheimer's disease. J. Alzheimer's Dis. 2013, 37, 453-459. [CrossRef] [PubMed]

47. Liu, H.P.; Lin, W.Y.; Wang, W.F.; Tsai, C.H.; Wu, W.C.; Chiou, M.T.; Shen, C.P.; Wu, B.T.; Tsai, F.J. Genetic variability in copper-transporting P-type adenosine triphosphatase (ATP7B) is associated with Alzheimer's disease in a Chinese population. J. Biol. Regul. Homeost. Agents 2013, 27, 319-327. [PubMed]

48. Hoogenraad, T. Diagnosis. In Wilson's disease, 2nd ed.; Intermed Medical Publishers: Amsterdam, The Netherlands, 2001; pp. 109-137.

49. Squitti, R.; Simonelli, I.; Cassetta, E.; Lupoi, D.; Rongioletti, M.; Ventriglia, M.; Siotto, M. Patients with Increased Non-Ceruloplasmin Copper Appear a Distinct Sub-Group of Alzheimer's Disease: A Neuroimaging Study. Curr. Alzheimer Res. 2017, 14, 1318-1326. [CrossRef]

50. James, S.A.; Volitakis, I.; Adlard, P.A.; Duce, J.A.; Masters, C.L.; Cherny, R.A.; Bush, A.I. Elevated labile Cu is associated with oxidative pathology in Alzheimer's Disease. Free Radic. Biol. Med. 2012, 52, 298-302. [CrossRef]

51. Bucossi, S.; Mariani, S.; Ventriglia, M.; Polimanti, R.; Gennarelli, M.; Bonvicini, C.; Pasqualetti, P.; Scrascia, F.; Migliore, S.; Vernieri, F.; et al. Association between the c. 2495 A>G ATP7B Polymorphism and Sporadic Alzheimer's Disease. Int. J. Alzheimer's Dis. 2011, 2011, 973692. [CrossRef]

52. Bucossi, S.; Polimanti, R.; Mariani, S.; Ventriglia, M.; Bonvicini, C.; Migliore, S.; Manfellotto, D.; Salustri, C.; Vernieri, F.; Rossini, P.M.; et al. Association of K832R and R952K SNPs of Wilson's disease gene with Alzheimer's disease. J. Alzheimer's Dis. 2012, 29, 913-919. [CrossRef] [PubMed]

53. McCann, C.J.; Jayakanthan, S.; Siotto, M.; Yang, N.; Osipova, M.; Squitti, R.; Lutsenko, S. Single nucleotide polymorphisms in the human ATP7B gene modify the properties of the ATP7B protein. Metallomics 2019, 11, 1128-1139. [CrossRef] [PubMed]

54. Mercer, S.W.; Wang, J.; Burke, R. In Vivo Modeling of the Pathogenic Effect of Copper Transporter Mutations That Cause Menkes and Wilson Diseases, Motor Neuropathy, and Susceptibility to Alzheimer's Disease. J. Biol. Chem. 2017, 292, 4113-4122. [CrossRef] [PubMed]

55. Salustri, C.; Siotto, M.; Bucossi, S.; Squitti, R. Metals Involvement in Alzheimer's Disease-A Patho-Genetic View. In Alzheimer's Disease-Challenges for the Future; Zerr, P.I., Ed.; InTech: London, UK, 2015; Volume 4. [CrossRef] 
56. Squitti, R.; Polimanti, R. Copper hypothesis in the missing hereditability of sporadic Alzheimer's disease: ATP7B gene as potential harbor of rare variants. J. Alzheimer's Dis. 2012, 29, 493-501. [CrossRef] [PubMed]

57. Squitti, R.; Polimanti, R. Copper phenotype in Alzheimer's disease: Dissecting the pathway. Am. J. Neurodegener. Dis. 2013, 2, 46-56. [PubMed]

58. Squitti, R.; Polimanti, R.; Siotto, M.; Bucossi, S.; Ventriglia, M.; Mariani, S.; Vernieri, F.; Scrascia, F.; Trotta, L.; Rossini, P.M. ATP7B variants as modulators of copper dyshomeostasis in Alzheimer's disease. Neuromolecular Med. 2013, 15, 515-522. [CrossRef]

59. Squitti, R.; Siotto, M.; Bucossi, S.; Polimanti, R. In silico investigation of the ATP7B gene: Insights from functional prediction of non-synonymous substitution to protein structure. Biometals 2014, 27, 53-64. [CrossRef] [PubMed]

60. Squitti, R.; Siotto, M.; Ivanova, I.; Rongioletti, M. ATP7B and Alzheimer disease. In Clinical and Translational Perspectives on WILSON DISEASE; Kerkar, N., Roberts, E.A., Eds.; Elsevier B.V.: Amsterdam, The Netherlands, 2019; Volume 42, pp. 427-436.

61. Squitti, R.; Ventriglia, M.; Gennarelli, M.; Colabufo, N.A.; El Idrissi, I.G.; Bucossi, S.; Mariani, S.; Rongioletti, M.; Zanetti, O.; Congiu, C.; et al. Non-Ceruloplasmin Copper Distincts Subtypes in Alzheimer's Disease: A Genetic Study of ATP7B Frequency. Mol. Neurobiol. 2017, 54, 671-681. [CrossRef]

62. Telianidis, J.; Hung, Y.H.; Materia, S.; Fontaine, S.L. Role of the P-Type ATPases, ATP7A and ATP7B in brain copper homeostasis. Front. Aging Neurosci. 2013, 5, 44. [CrossRef]

63. Pal, A.; Siotto, M.; Prasad, R.; Squitti, R. Towards a unified vision of copper involvement in Alzheimer's disease: A review connecting basic, experimental, and clinical research. J. Alzheimer's Dis. 2015, 44, 343-354. [CrossRef]

64. Squitti, R.; Tecchio, F.; Ventriglia, M. The Role of Copper in Human Diet and Risk of Dementia. Curr. Nutr. Rep. 2015, 4, 114-125. [CrossRef]

65. Sparks, D.L.; Schreurs, B.G. Trace amounts of copper in water induce-amyloid plaques and learning deficits in a rabbit model of Alzheimer's disease. Proc. Natl. Acad. Sci. USA 2003, 100, 11065-11069. [CrossRef]

66. Sparks, D.L.; Friedland, R.; Petanceska, S.; Schreurs, B.G.; Shi, J.; Perry, G.; Smith, M.A.; Sharma, A.; Derosa, S.; Ziolkowski, C.; et al. Trace copper levels in the drinking water, but not zinc or aluminum influence CNS Alzheimer-like pathology. J. Nutr. Health Aging. 2006, 10, 247-254. [PubMed]

67. Lu, J.; Zheng, Y.L.; Wu, D.M.; Sun, D.X.; Shan, Q.; Fan, S.H. Trace amounts of copper induce neurotoxicity in the cholesterol-fed mice through apoptosis. FEBS Lett. 2006, 580, 6730-6740. [CrossRef] [PubMed]

68. Arnal, N.; Castillo, O.; de Alaniz, M.J.; Marra, C.A. Effects of Copper and/or Cholesterol Overload on Mitochondrial Function in a Rat Model of Incipient Neurodegeneration. Int. J. Alzheimer's Dis. 2013, 2013, 645379. [CrossRef] [PubMed]

69. Yao, D.; Jing, T.; Niu, L.; Huang, X.; Wang, Y.; Deng, X.; Wang, M. Amyloidogenesis induced by diet cholesterol and copper in a model mouse for Alzheimer's disease and protection effects of zinc and fluvastatin. Brain Res. Bull. 2018, 143, 1-8. [CrossRef]

70. Abolaji, A.O.; Fasae, K.D.; Iwezor, C.E.; Aschner, M.; Farombi, E.O. Curcumin attenuates copper-induced oxidative stress and neurotoxicity in Drosophila melanogaster. Toxicol. Rep. 2020, 7, 261-268. [CrossRef] [PubMed]

71. Lamtai, M.; Zghari, O.; Ouakki, S.; Marmouzi, I.; Mesfioui, A.; EI Hessni, A.; Ouichou, A. Chronic copper exposure leads to hippocampus oxidative stress and impaired learning and memory in male and female rats. Toxicol. Res. 2020. [CrossRef]

72. Singh, I.; Sagare, A.P.; Coma, M.; Perlmutter, D.; Gelein, R.; Bell, R.D.; Deane, R.J.; Zhong, E.; Parisi, M.; Ciszewski, J.; et al. Low levels of copper disrupt brain amyloid-beta homeostasis by altering its production and clearance. Proc. Natl. Acad. Sci. USA 2013, 110, 14771-14776. [CrossRef] [PubMed]

73. Yu, J.; Luo, X.; Xu, H.; Ma, Q.; Yuan, J.; Li, X.; Chang, R.C.; Qu, Z.; Huang, X.; Zhuang, Z.; et al. Identification of the Key Molecules Involved in Chronic Copper Exposure-Aggravated Memory Impairment in Transgenic Mice of Alzheimer's Disease Using Proteomic Analysis. J. Alzheimer's Dis. 2015, 44, 455-469. [CrossRef]

74. Huat, T.J.; Camats-Perna, J.E.; Newcombe, A.; Valmas, N.; Kitazawa, M.; Medeiros, R. Metal Toxicity Links to Alzheimer's Disease and Neuroinflammation. J. Mol. Biol. 2019, 431, 1843-1868. [CrossRef]

75. Brewer, G.J. Copper-2 Hypothesis for Causation of the Current Alzheimer's Disease Epidemic Together With Dietary Changes That Enhance the Epidemic. Chem. Res. Toxicol. 2017, 30, 763-768. [CrossRef] 
76. Esmieu, C.; Guettas, D.; Conte-Daban, A.; Sabater, L.; Faller, P.; Hureau, C. Copper-Targeting Approaches in Alzheimer's Disease: How To Improve the Fallouts Obtained From in Vitro Studies. Inorg. Chem. 2019, 58, 13509-13527. [CrossRef] [PubMed]

77. Lamichhane, J.R.; Osdaghi, E.; Behlau, F.; Köhl, J.; Jones, J.B.; Aubertot, J.N. Thirteen decades of antimicrobial copper compounds applied in agriculture. A review. Agron. Sustain. Dev. 2018, 38, 1-18. [CrossRef]

78. Fishel, F.M. Pest Management and Pesticides: A Historical Perspective. Available online: http://moodle. toxoer.com/pluginfile.php/8421/mod_imscp/content/1/Pest_Management_and_Pesticides.pdf (accessed on 24 April 2020).

79. Lara, W.H.; Toledo, M.; Takahashi, M.Y. Teores de cobre em café torrado e moído e em café bebida. Rev. Inst. Adolfo Lutz 1975, 35, 17-22.

80. Almeida, O.C.; Almeida, L.C.C.; Bezerra, J.L. Estudo de fungicidas à base de cobre no controle da vassourade-bruxa do cacaueiro no sudeste da Bahia. Agrotrópica 2002, 14, 97-100.

81. Can Organic Agriculture Give Up Copper As a Crop Protection Product? Available online: https://inra-dam-front-resources-cdn.brainsonic.com/ressources/afile/444379-9fbc6-resource-expertisecuivre-en-ab-8-pages-anglais.pdf (accessed on 24 April 2020).

82. FAO-Guidelines for the Production, Processing, Labelling and Marketing of Organically Produced Foods1. Available online: http://www.fao.org/docs/eims/upload/230124/CXG_032e.pdf (accessed on 24 April 2020).

83. Instrução Normativa Interministerial No 28 de 08 de Junho de 2011 (Produção de Organismos Aquáticos).pdf-Português (Brasil). Available online: https://www.gov.br/agricultura/pt-br/assuntos/ sustentabilidade/organicos/legislacao/portugues/instrucao-normativa-interministerial-no-28-de-08-dejunho-de-2011-producao-de-organismos-aquaticos.pdf/view (accessed on 27 April 2020).

84. Ministério da Agricultura, Pecuária e Abastecimento. Available online: http://www.agricultura.gov.br/ assuntos/sustentabilidade/organicos/legislacao/portugues/instrucao-normativa-no-46-de-06-de-outubrode-2011-producao-vegetal-e-animal-regulada-pela-in-17-2014.pdf/view (accessed on 24 January 2020).

85. Ministério da Agricultura, Pecuária e Abastecimento. Available online: http://www.agricultura.gov.br/ assuntos/sustentabilidade/organicos/legislacao/portugues/instrucao-normativa-no-17-de-18-de-junho-de2014.pdf/view (accessed on 24 January 2020).

86. ifoam_eu_copper_minimisation_in_organic_farming_may2018_0.pdf. Available online: https://www.ifoameu.org/sites/default/files/ifoam_eu_copper_minimisation_in_organic_farming_may2018_0.pdf (accessed on 30 January 2020).

87. Kuhne, S.; Roßberg, D.; Rohrig, P.; Mering, F.; Weihrauch, F.; Kanthak, S.; Kienzle, J.; Patzwahl, W.; Reiners, E.; Gitzel, J. The Use of Copper Pesticides in Germany and the Search for Minimization and Replacement Strategies. Org. Farming 2017, 3, 66-75. [CrossRef]

88. USDA-United States Department of Agriculture. Available online: https://www.ecfr.gov/cgi-bin/text-idx? $\mathrm{c}=$ ecfr\&SID=9874504b6f1025eb0e6b67cadf9d3b40\&rgn=div6\&view=text\&node=7:3.1.1.9.32.7\&idno=7 (accessed on 30 January 2020).

89. Calda Bordalesa: Utilidades e Preparo. Ministério da Agricultura. Available online: https://ainfo.cnptia. embrapa.br/digital/bitstream/item/38833/1/FOL200837.pdf (accessed on 20 January 2020).

90. EAOPS—East African Organic Products Standard. Available online: https://law.resource.org/pub/eac/ibr/eas. 456.2007.html (accessed on 20 January 2020).

91. EAC. Aid for Trade Case Story: The East African Organic Products Standard Submission by the United Nations Environment Programme. Available online: https://www.oecd.org/aidfortrade/47719232.pdf. (accessed on 24 January 2020).

92. Aplicação de calda bordalesa em frutíferas. Available online: http://www.agricultura.gov.br/assuntos/ sustentabilidade/organicos/fichas-agroecologicas/arquivos-sanidade-vegetal/2-aplicacao-de-caldabordalesa-em-frutiferas.pdf (accessed on 24 January 2020).

93. Sistema de produção de uva de mesa do norte de Minas Gerais. Available online: https://sistemasdeproducao. cnptia.embrapa.br/FontesHTML/Uva/MesaNorteMinas/tecnologia.htm (accessed on 12 January 2020).

94. Rusjan, D.; Strlič, M.; Pucko, D.; Korošec-Koruza, Z. Copper accumulation regarding the soil characteristics in Sub-Mediterranean vineyards of Slovenia. Geoderma 2007, 141, 111-118. [CrossRef]

95. Calviño, D.F.; Nóvoa-Muñoz, J.C.; Díaz-Raviña, M.; Arias-Estévez, M. Copper accumulation and fractionation in vineyard soils from temperate humid zone (NW Iberian Peninsula). Geoderma 2009, 153, 119-129. [CrossRef] 
96. Tóth, G.; Hermann, T.; Silva, M.R. Heavy metals in agricultural soils of the European Union with implications for food safety. Environ. Int. 2016, 88, 299-309. [CrossRef]

97. Sacristán, D.; Carbó, E. Copper Contamination in Mediterranean Agricultural Soils: Soil Quality Standards and Adequate Soil Management Practices for Horticultural Crops. In Soil Contamination-Current Consequences and Further Solutions; Larramendy, M.L., Soloneski, S., Eds.; InTech: London, UK, 2016; Volume 4. [CrossRef]

98. Wu, C.; Luo, Y.; Zhang, L. Variability of copper availability in paddy fields in relation to selected soil properties in southeast China. Geoderma 2010, 156, 200-206. [CrossRef]

99. Ávila, G.; Gaete, H.; Sauvé, S.; Neaman, A. Organic matter reduces copper toxicity for the earthworm Eisenia fetida in soils from mining areas in Central Chile. Chil. J. Agric. Res. 2009, 69, 252-259. [CrossRef]

100. Pietrzak, U.; McPhail, D.C. Copper accumulation, distribution and fractionation in vineyard soils of Victoria, Australia. Geoderma 2004, 122, 151-166. [CrossRef]

101. Xu, J.; Yang, L.; Wang, Z.; Dong, G.; Huang, J.; Wang, Y. Toxicity of copper on rice growth and accumulation of copper in rice grain in copper contaminated soil. Chemosphere 2006, 62, 602-607. [CrossRef] [PubMed]

102. Mallmann, F.J.K.; Rheinheimer, D.S.; Ceretta, C.A.; Cella, C.; Minella, J.P.G.; Guma, R.L.; Filipovi, V.; Oort, F.; Šimunek, J. Soil tillage to reduce surface metal contamination-Model development and simulations of zinc and copper content profiles in a pig slurry-amended soil. Agric. Ecosyst. Environ. 2014, 196, 59-68. [CrossRef]

103. National Research Council (US) Committee on Copper in Drinking Water. Copper in Drinking Water. Available online: https://www.ncbi.nlm.nih.gov/books/NBK225402/ (accessed on 12 January 2020).

104. Shen, X.L.; Yu, J.H.; Zhang, D.F.; Xie, J.X.; Jiang, H. Positive relationship between mortality from Alzheimer's disease and soil metal concentration in mainland China. J. Alzheimer's Dis. 2014, 42, 893-900. [CrossRef] [PubMed]

105. Morris, M.C.; Evans, D.A.; Tangney, C.C.; Bienias, J.L.; Schneider, J.A.; Wilson, R.S.; Scherr, P.A. Dietary Copper and High Saturated and trans Fat Intakes Associated With Cognitive Decline. Arch. Neurol. 2006, 63, 1085-1088. [CrossRef]

106. EFSA (European Food Safety Authority) Peer review of the pesticide risk assessment of the active substance copper compounds. EFSA J. 2018, 16, 5152.

107. Napoli, M.; Cecchi, S.; Grassi, C.; Baldi, A.; Zanchi, C.A.; Orlandini, S. Phytoextraction of copper from a contaminated soil using arable and vegetable crops. Chemosphere 2019, 219, 122-129. [CrossRef]

108. Rahman, M.M.; Azirun, S.M.; Boyce, A.N. Enhanced Accumulation of Copper and Lead in Amaranth (Amaranthus paniculatus), Indian Mustard (Brassica juncea) and Sunflower (Helianthus annuus). PLoS ONE 2013, 8, e62941. [CrossRef]

109. Hummes, A.P.; Bortoluzzi, E.C.; Tonini, V.; Silva, L.; Petry, C. Transfer of Copper and Zinc from Soil to Grapevine-Derived Products in Young and Centenarian Vineyards. Water Air Soil Pollut. 2019, 230, 150-161. [CrossRef]

110. Santos, C.E.; Debastiani, R.; Souza, V.S.; Peretti, D.E.; Jobim, P.F.; Yoneama, M.L.; Amaral, L.; Dias, J.F. The influence of the winemaking process on the elemental composition of the Marselan red wine. J. Sci. Food Agric. 2019, 99, 4642-4650. [CrossRef]

111. Donici, A.C.; Bunea, I.; Călugăr, A.; Harsan, E.; Bora, F.D. Investigation of the Copper Content in Vineyard Soil, Grape, Must and Wine in the Main Vineyards of Romania: A Preliminary Study. Bull. UASVM Hortic. 2019, 76, 31-46. [CrossRef]

112. Rehman, M.; Liu, L.; Wang, Q.; Saleem, M.H.; Bashir, S.; Ullah, S.; Peng, D. Copper environmental toxicology, recent advances, and future outlook: A review. Environ. Sci. Pollut. Res. 2019, 26, 18003-18016. [CrossRef] [PubMed]

113. Alexander, P.D.; Alloway, B.J.; Dourado, A.M. Genotypic variations in the accumulation of $\mathrm{Cd}, \mathrm{Cu}, \mathrm{Pb}$ and Zn exhibited by six commonly grown vegetables. Environ. Pollut. 2006, 144, 736-745. [CrossRef] [PubMed]

114. Garrido, L.R.; Botton, M. Recomendações Técnicas para o Manejo das Pragas e Doenças Fúngicas da Videira na Região Sul do Brasil. In Circula Téchnica; Empresa Brasileira de Pesquisa Agropecuária: Bento Gonçalves, RS, Brasil, 2015; Volume 117, pp. 3-23.

115. 1516729946. Available online: http://www.ihara.com.br/upload/produtos/fispq/1516729946.pdf (accessed on 24 January 2020).

116. Massie, H.R.; Aiello, V.R.; Iodice, A.A. Changes with age in copper and superoxide dismutase levels in brains of C57BL/6J mice. Mech. Ageing Dev. 1979, 10, 93-99. [CrossRef] 
117. Zatta, P.; Drago, D.; Zambenedetti, P.; Bolognin, S.; Nogara, E.; Peruffo, A.; Cozzi, B. Accumulation of copper and other metal ions, and metallothionein I/II expression in the bovine brain as a function of aging. J. Chem. Neuroanat. 2008, 36, 1-5. [CrossRef] [PubMed]

118. Vasudevaraju, P.; Bharathi, T.J.; Shamasundar, N.M.; Subba Rao, K.; Balaraj, B.M.; Rao, K.S.J.; Sathyanarayana Rao, T.S. New evidence on Iron, Copper accumulation and Zinc depletion and its correlation with DNA integrity in aging human brain regions. Indian J. Psychiatry 2010, 52, 104-144.

119. Vanacore, R.; Eskew, J.D.; Sung, L.; Davis, T.; Smith, A. Safe Coordinated Trafficking of Heme and Iron With Copper Maintain Cell Homeostasis: Modules From the Hemopexin System. Biometals 2019, 32, 355-367. [CrossRef]

120. Pohanka, M. Copper and copper nanoparticles toxicity and their impact on basic functions in the body. Bratisl Lek Listy 2019, 120, 397-409. [CrossRef]

121. Lavado, L.K.; Zhang, M.H.; Patel, K.; Khan, S.; Patel, U.K. Biometals as Potential Predictors of the Neurodegenerative Decline in Alzheimer's Disease. Cureus 2019, 5, 1-11. [CrossRef]

122. Hsu, H.W.; Bondy, S.C.; Kitazawa, M. Environmental and Dietary Exposure to Copper and Its Cellular Mechanisms Linking to Alzheimer's Disease. Toxicol. Sci. 2018, 163, 338-345. [CrossRef] [PubMed]

123. Pal, I.; Roy, M.; Dey, S.G. Active-site Environment of $\mathrm{Cu}$ Bound Amyloid $\beta$ and Amylin Peptides. J. Biol. Inorg. Chem. 2019, 24, 1245-1259. [CrossRef] [PubMed]

124. La Torre, A.; Iovino, V.; Caradonia, F. Copper in plant protection: Current situation and prospects. Phytopathol. Mediterr. 2018, 57, 201-236.

125. Pertot, I.; Bilali, H.E.; Simeone, V.; Vecchione, A.; Zulini, L. Efficacy evaluation and phytotoxicity assessment of traditional and new copper compounds used in copper reduction strategies in organic viticulture in northern and southern Italy environments. Integr. Prot. Vitic. IOBC/wprs Bull. 2006, 29, 61-65.

126. 278-284 Smith J et al._SRUC. Available online: http://www.sruc.ac.uk/downloads/file/2022/278-284 (accessed on 24 March 2020).

127. Torre, A.L.; Righi, L.; Iovino, V.; Battaglia, V. Control of late blight in organic farming with low copper dosages or natural products as alternatives to copper. Eur. J. Plant Pathol. 2019, 155, 769-778. [CrossRef]

128. Moonen, A.C.; Bàrberi, P. Functional biodiversity: An agroecosystem approach. Agric. Ecosyst. Environ. 2008, 127, 7-21. [CrossRef]

129. Bankina, B.; Bimsteine, G.; Paulovska, L.; Paura, L.; Pavlovica, O.; Kaneps, J.; Neusa-Luca, I.; Roga, A.; Fridmanis, D. Effects of soil tillage and crop rotation on the development of wheat stem base diseases. Can. J. Plant Pathol. 2019, 41, 435-442. [CrossRef]

130. Runno-Paurson, E.; Laaniste, P.; Eremeev, V.; Tahtjarv, T.; Kaurilind, E.; Tosens, T.; Niinemets, U.; Williams, I.H. Does winter oilseed rape as a winter cover crop influence potato late blight development in an organic crop rotation? Biol. Agric. Hortic. 2019, 36, 71-83. [CrossRef]

131. Page, K.; Dang, Y.; Dalal, R. Impacts of conservation tillage on soil quality, including soil-borne crop diseases, with a focus on semi-arid grain cropping systems. Australas. Plant Pathol. 2013, 42, 363-377. [CrossRef]

132. Lage, D.A.C.; Marouelli, W.A.; Cafe, A.C. Management of powdery mildew and behaviour of late blight under different irrigation configurations in organic tomato. Crop Prot. 2019, 125, 104886. [CrossRef]

133. Merwin, I.A.; Wilcox, W.F.; Stiles, W.C. Influence of orchard ground cover management on the development of Phytophthora crown and root rots of apple. Plant Dis. 1992, 76, 199-205. [CrossRef]

134. Vukicevich, E.; Lowery, D.T.; Urbez-Torres, J.R.; Bowen, P.; Hart, M. Groundcover management changes grapevine root fungal communities and plant-soil feedback. Plant Soil 2018, 424, 419-433. [CrossRef]

135. Holb, I.J. Effect of pruning on apple scab in organic apple production. Plant Dis. 2005, 89, 611-618. [CrossRef] [PubMed]

136. Commission Implementing Regulation (EU) 2015/232 of 13 February 2015. Available online: https://eur-lex. europa.eu/legal-content/EN/TXT/PDF/?uri=CELEX:32015R0232\&from=EN (accessed on 24 April 2020).

137. Farming without plant protection products Can we grow without using herbicides, fungicides and insecticides? Available online: http://www.europarl.europa.eu/cmsdata/185760/EPRS_IDA(2019)634416_EN. pdf (accessed on 24 April 2020).

(C) 2020 by the authors. Licensee MDPI, Basel, Switzerland. This article is an open access article distributed under the terms and conditions of the Creative Commons Attribution (CC BY) license (http://creativecommons.org/licenses/by/4.0/). 